A New Species of Hybanthus (Violaceae) from Panama

Author(s): Carol A. Todzia

Source: Annals of the Missouri Botanical Garden, Vol. 76, No. 1 (1989), pp. 360-362

Published by: Missouri Botanical Garden Press

Stable URL: http://www.jstor.org/stable/2399357

Accessed: 11-06-2015 17:17 UTC

Your use of the JSTOR archive indicates your acceptance of the Terms \& Conditions of Use, available at http://www.jstor.org/page/ info/about/policies/terms.jsp

JSTOR is a not-for-profit service that helps scholars, researchers, and students discover, use, and build upon a wide range of content in a trusted digital archive. We use information technology and tools to increase productivity and facilitate new forms of scholarship. For more information about JSTOR, please contact support @ jstor.org. 


\section{A NEW SPECIES OF HYBANTHUS (VIOLACEAE) FROM PANAMA}

Hybanthus is a very poorly known genus of 150 species of herbs, trees, and shrubs from the Old and New World. The last synopsis of the genus throughout its range enumerated 32 species in the New World (Melchior, 1925); Morton (1944) provided the most recent synopsis of the Central American species. The new species proposed here, $H y$ banthus jefensis, is clearly distinct from all species in Central America and is not placed within any species presently known from Colombia (Smith \& Fernández-Pérez, 1954).

Hybanthus jefensis Todzia, sp. nov. TYPE: Panama. Panamá: Cerro Jefe, near Río Indio, 2,100-2,200 ft., 17 Feb. 1968, Dwyer 1969 (holotype, MO). Figure 1.

Frutices caulibus juvenibus strigulosis; stipulae anguste triangulares in siccitate chartaceae; folia alterna crenulata glabra in siccitate rubropunctata in pagina inferna; inflorescentiae axillares fasciculatae in brachyblastis, floribus $1-4$ in pedicellis $1-2 \mathrm{~cm}$ longis; petalum panduratum $0.7-1 \mathrm{~cm}$ longum rotundatum ad apicem; capsulae $7-8$ $\mathrm{mm}$ longae.

Shrubs i-2.5 m tall; older stems terete, reddish brown, glabrous, sparsely branched; younger stems terete to quadrangular, dark to light brown, strigulose with hairs curving upwards, with leaves erect and \pm adpressed to stems; stipules narrowly triangular, 1.5-2 $\mathrm{mm}$ long, ca. $0.5 \mathrm{~mm}$ broad at base, drying chartaceous, brown. Leaves alternate, elliptic to narrowly obovate, 3-12 cm long, 1-3.8 cm broad; petioles terete, $0.5-1 \mathrm{~cm}$ long, glabrous; the blade acute at apex, attenuate at base, smooth, glabrous, drying chartaceous with red dots and reticulations beneath, each side with 5-7 usually obscure, gradually arcuate lateral veins; the margin crenulate with 8-17 glandular teeth on each side. Inflorescences 1-4-flowered, axillary, fasciculate on short shoots ca. $2 \mathrm{~mm}$ long; bracts inserted at base of pedicels, lanceolate, 1-2 mm long, acute, drying chartaceous, brown; bracteoles on lower half of pedicels $0.5-1 \mathrm{~mm}$ long, lanceolate; pedicels $1-$ $2 \mathrm{~cm}$ long, slender, glabrous, articulate above the middle. Flowers white, zygomorphic; sepals 5, lanceolate, 2-2.5 mm long, acute, glabrous; lateral petals 4, 4-5 $\mathrm{mm}$ long, falcate, with irregularly crenate margins; anterior petal pandurate, 0.7-1 cm long, with claw 4-5 mm long, sparsely pilose, lip 3-5 mm long, 4-5 $\mathrm{mm}$ broad at widest point, rounded at apex, glabrous; stamens 5 , sessile, free or connate; filaments very short, the anterior 2 stamens with a subglobose gland dorsally; anthers 1-1.5 mm long, sparsely pilose dorsally and at base; connective appendages ca. $2 \mathrm{~mm}$ long, 0.5$1 \mathrm{~mm}$ broad, rounded at apex, membranaceous; ovary globose, ca. $1 \mathrm{~mm}$ long, glabrous, with 3 locules containing 1-2 ovules each; style $2-3 \mathrm{~mm}$ long, curved at apex. Capsules loculicidally and elastically 3-valvate, 7-8 $\mathrm{mm}$ long, glabrous, with 3-6 seeds, often with persistent style and sepals; seeds globose to ovoid, 2-3 mm diam., smooth, black.

Distribution, habitat, and phenology. Endemic to the Cerro Jefe region of the Prov. Panamá, Panama, at 650-1,000 $\mathrm{m}$ elevation in disturbed and undisturbed premontane wet forest. Flowering and fruiting October, November, December, January, and February.

Representative specimens examined. Panama. PANAMÁ: region of Cerro Jefe, ca. 1,000 m, 3 Oct. 1969, Correa et al. 1598 (MO); between Cerro Azul and Cerro Jefe, 24 Dec. 1967, Dressler 3270 (MO); between Cerro Jefe and La Eneida, 17 Jan. 1968, Dwyer et al. 8195 (MO); $6.5 \mathrm{~km}$ by road $\mathrm{N}$ of Lago Cerro Azul, 650-730 m, 13 Jan. 1974, Nee 9292 (MO).

This species is distinctive by virtue of its small crenulate leaves with red dots and punctations when dried; axillary inflorescences fasciculate on short shoots ca. $2 \mathrm{~mm}$ long; stipules that are chartaceous when dry; and pedicels 1-2 mm long. The anterior petal, one of the most diagnostic characters of the genus, is pandurate, $0.7-1 \mathrm{~cm}$ long, and rounded apically. In southern Central America $H$. jefensis appears to be most similar to $H$. guanacastensis Standley from which the new species differs by its chartaceous (vs. indurate) stipules, crenulate (vs. doubly serrate) leaf margins, shorter anterior petals (0.7-1 cm long vs. ca. $1.2 \mathrm{~cm}$ long), and smaller capsules (0.7-0.8 cm long vs. $1.5-2 \mathrm{~cm}$ long). Hybanthus jefensis is probably most closely related to $H$. sylvicola Standley \& Steyerm. of southern

AnN. Missouri Bot. Gard. 76: 360-362. 1989. 


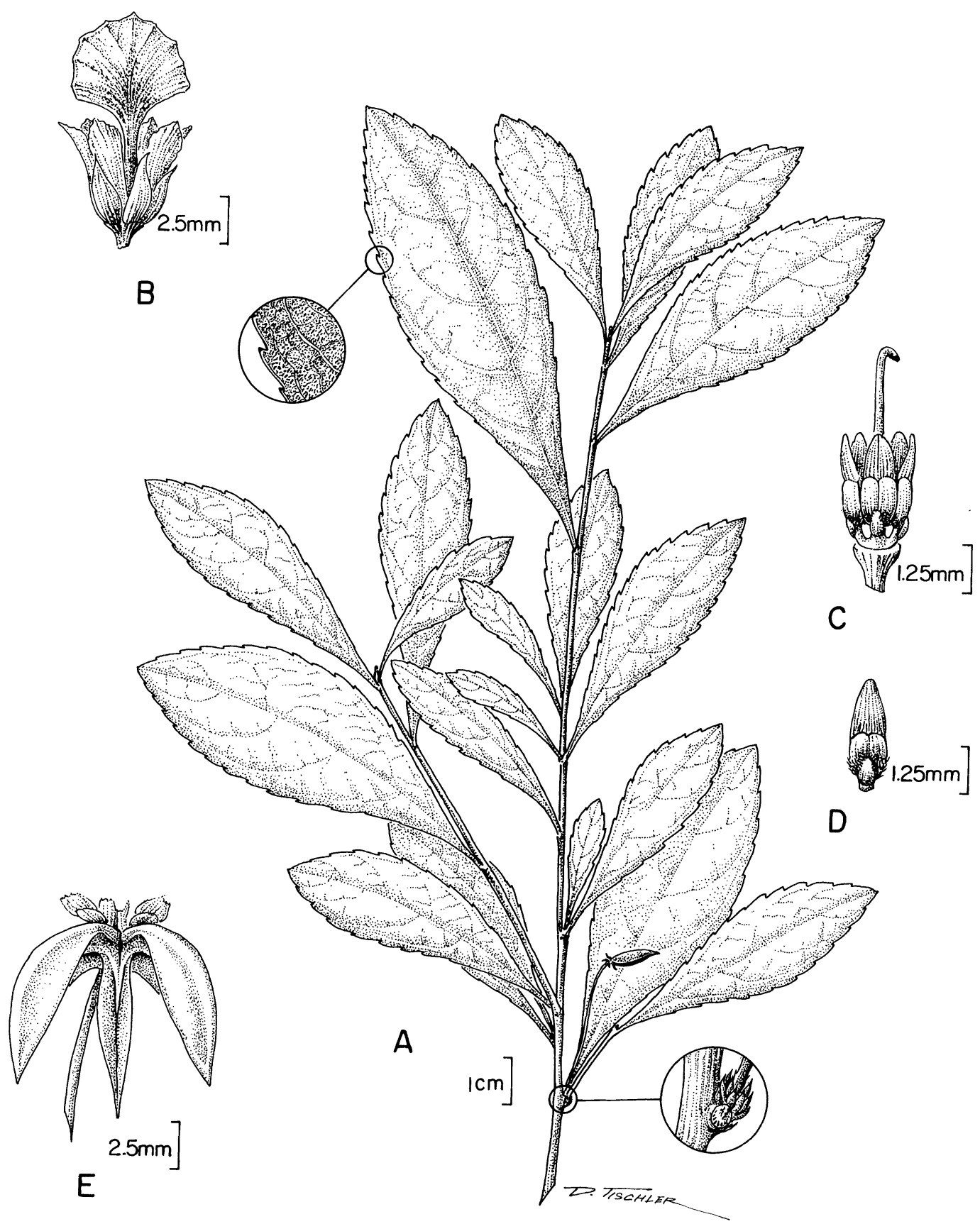

FIGURE 1. Hybanthus jefensis. - A. Habit with close-ups of leaf margin and leaf axil showing bracts at base of fascicles. - B. Flower. - C. Close-up of anthers and style with sepals and petals removed. - D. Close-up of an anterior anther. (A-D from Dwyer 1969.) - E. Fruit (from Dwyer 8195).

Mexico and Guatemala but differs by having strigulose (vs. glabrous) young branches, leaves with (vs. without) red punctations beneath, and lip 0.7$1 \mathrm{~cm}$ vs. $1.1-1.3 \mathrm{~cm}$ long.

Hybanthus jefensis is yet another endemic to the region of Cerro Jefe in central Panama (Lewis, 1971). In addition to the three Hybanthus species reported in the Flora of Panama (Robyns, 1967), two other species are presently known from Panama (D'Arcy, 1987; pers. obs). 


\section{Key to Hybanthus in Panama}

la. Shrubs or small trees, woody; flowers in fascicles borne on short shoots.

2a. Shrubs or small trees $1-7 \mathrm{~m}$ tall; capsules $0.7-2 \mathrm{~cm}$ long.

3a. Stipules drying white, indurate; leaves sharply serrate, drying uniform in color beneath, without red dots; anterior petal 1.2-4 cm long; capsules $1-2 \mathrm{~cm}$ long.

4a. Anterior petal up to $4 \mathrm{~cm}$ long; capsules $1.5-2 \mathrm{~cm}$ long; seeds $4-5 \mathrm{~mm}$ long ...... H. prunifolius 4b. Anterior petal ca. $1.2 \mathrm{~cm}$ long; capsules $1-1.3 \mathrm{~cm}$ long; seeds $2-3 \mathrm{~mm}$ long

H. guanacastensis

3b. Stipules drying brown, chartaceous; leaves crenulate, drying with red dots and reticulations beneath;

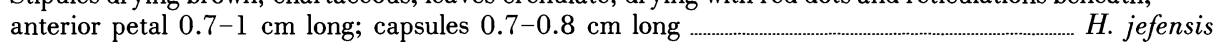
2b. Shrubs less than $1 \mathrm{~m}$ tall; capsules $0.3-0.6 \mathrm{~cm}$ long H. jefensis
H. galeottii

lb. Annual or perennial herbs, not woody; flowers solitary, not borne on short shoots.

5a. Leaves opposite to subopposite at base, elliptic to lanceolate, long-attenuate at apex; plants annual ....

5b. Leaves alternate, ovate to oblong-ovate, acute at apex; plants perennial H. attenuatus

I thank Guy Nesom for providing the Latin description, Doris Lee Tischler for the handsome illustration, and James W. Grimes, George Rogers, and Henk van der Werff for reviewing the manuscript. This work was supported by a Noyes Foundation grant to the Missouri Botanical Garden.

\section{Literature Cited}

D'Arcy, W. G. 1987. Flora of Panama. Checklist and Index. Part 1: The Introduction and Checklist. Monogr. Syst. Bot. Missouri Bot. Gard. 17.

LEwIS, W. H. 1971. High floristic endemism in low cloud forests of Panama. Biotropica 3: 78-80.
MelchioR, M. 1925. Violaceae. In: A. Engler \& K. Prantl, Die Natürlichen Pflanzenfamilien, ed. 2. 2l: 329-377.

MorTon, C. V. 1944. The genus Hybanthus in continental North America. Contr. U.S. Natl. Herb. 29: $74-82$.

Robyns, A. 1967. Violaceae. In: R. E. Woodson, Jr. \& R. W. Schery (editors), Flora of Panama. Ann. Missouri Bot. Gard. 54: 65-84.

Smith, L. B. \& A. Fernández-Pérez. 1954. Revisio Violacearum Colombiae. Caldasia 6(28): 83-181.

- Carol A. Todzia, Department of Botany, University of Texas, Austin, Texas 78712, U.S.A. 